KAROLINA SIKORSKA

Uniwersytet Mikołaja Kopernika w Toruniu

„JELENIE NA RYKOWISKU”: O DEMONACH SZTUKI I GRANICACH SZTUKI POPULARNEJ

Problem z określeniem, co kryje się za sformułowaniem „sztuka popularna”, pojawia się już w momencie, gdy próbujemy zbudować jednoznaczną, ogólną definicję samej sztuki - ta bowiem, jak zauważył np. w latach 70. XX wieku Władysław Tatarkiewicz, nie daje się tłumaczyć przez jedno obowiązujące zwyczajowo kryterium (Tatarkiewicz 2012: 40-52) ${ }^{1}$. Do podobnych rozstrzygnięć dochodzi Arthur C. Danto, forsujący tezę o końcu sztuki lub raczej o końcu pewnej narracji o niej ${ }^{2}$, podkreślając, że współcześnie „sztuka może być tym wszystkim, czego zażyczą sobie artyści i mecenasi" (Danto 2013: 71). Mimo to w praktyce, posługując się dominującymi w danym czasie konwencjami, bez większych wątpliwości wskażemy na „sztukę”, „dzieło”; łatwo stwierdzimy przynależność określonego artefaktu bądź do sfery działań artystycznych, bądź do sfery życia codziennego, których granice są wyznaczane przez odmienne dyskursy (odpowiednio - muzealno-estetyczny i normatywno-obyczajowy). W tym kontekście interesujący wydaje się schemat zaproponowany przez Jamesa Clifforda - „system sztuka - kultura”, konstruowany przez odniesienie występujących w nim kategorii do autentyczności i przypisywanej jej kulturowej wartości, związanych z kolekcjonowaniem: „Ze wstępnego przeciwstawienia wyprowadzono przez negację cztery pojęcia. Wyznaczają one dwie osie, poziomą i pionową, oraz cztery strefy semantyczne pomiędzy nimi: (1) strefę autentycznych arcydzieł; (2) strefę autentycznych artefaktów; (3) strefę nieautentycznych arcydzieł, oraz (4) strefę nieautentycznych artefaktów" (Clifford 2000: 241). Badacz przekonuje, że między wskazanymi strefami zachodzi ciągły ruch: przedmioty o wartości kulturowej przemieszczają się w stronę sztuki (kiedy przypiszemy im właściwości estetyczne); arcydzieła przechodzą do strefy „autentycznych artefaktów”, kiedy są kontekstualizowane - umieszczane przede wszystkim w narracji historyczno-kulturowej (np. jako ilustrujące procesy społeczne zachodzące w określonym czasie); przedmioty ze strefy „nieautentycznych arcydzieł” przemieszczają się w górę, gdy zostają „zaklasyfikowane” jako dzieła sztuki (np. dzięki mocy „artystycznego gestu” umieszczone zostają w przestrzeni artystycznej, a później podlegają muzealizacji - jak ready-mades); ale do tej strefy „niekultury” „spadają z góry” również arcydzieła, kiedy zostaną rozpoznane jako falsyfikaty; ,przedmioty powszechnego użytku” ze sfery „nieautentycznych artefaktów” przemieszczają się do sfery „autentycznych artefaktów”, kiedy potraktuje się je jako unikatowe wytwory jakiejś społeczności lub jako znaki

1 Tatarkiewicz stwierdza, że choć „w spadku po XVIII wieku pozostały dwie definicje: sztuka jest wytwarzaniem piękna - i sztuka jest naśladowaniem”, to żadna z nich nie jest w XX wieku już wystarczająca, co więcej, kolejne, które się pojawiły - również nie sạ w stanie objać tego wszystkiego, co do sztuki zaliczymy. „Okazuje się szczególny stan rzeczy: posługujemy się wyrazem »sztuka« z sensem, pozwala on nam porozumieć się między sobą, mamy pojęcie sztuki - a określić go nie potrafimy. Jednakże ostatecznie nie może to dziwić: klasa przedmiotów nazywanych »sztuką jest bowiem nie tylko rozległa, ale i niejednolita. Tak niejednolita, że dawniejsze czasy - aż po Renesans - klasy tej w ogóle nie uformowały; dopiero czasy nowe połączyły mniejsze klasy - literaturę plastykę, sztuki czyste i stosowane - i usiłowały zdefiniować to szerokie pojęcie sztuki. Usiłowania te napotykały trudności. I obok prób definicji zjawił się w połowie XX wieku pogląd, że definicja sztuki nie tylko jest trudna, ale nie jest w ogóle możliwa” (Tatarkiewicz 2012: 40, 46).

${ }^{2},(\ldots)$ historia sztuki jako pewna ustrukturyzowana narracja dobiegła końca” (Danto 2013:195). 
określonego (minionego) czasu - „nieautentyczne artefakty” mogą przechodzić też do strefy „nieautentycznych arcydzieł”, gdy zyskają status wynalazków, istotnych innowacji technicznych (Clifford 2000: 242-244).

Ale czy utrzymując te wskazane przez Clifforda opozycje (zwłaszcza między sztuką a artefaktami), nie wpisujemy jednocześnie dzieła sztuki w przestrzeń elitarną, gdzie jest ono traktowane od razu jako „sztuka wysoka” (następuje zrównanie, utożsamienie sztuki ze sztuką wysoką), a „artefakt” w ogóle pozbawiony zostaje odniesień do pola artystycznego ${ }^{3}$ ? Oczywiście, sam Clifford zwraca uwagę, że jego propozycja nie jest całościowa, ma charakter historyczny i zaprojektowane w niej kategorie są w ciągłym ruchu. Mimo to, by dostrzec różnice między wskazanymi strefami, musimy założyć pewne ich dość stabilne właściwości, co nie znaczy, że przedmioty i praktyki „wędrujące” między tymi strefami nie przekształcają ich i same nie ulegają przeobrażeniom, nasiąkając właściwościami przestrzeni, które naznaczyły swoją obecnością.

Sztuka popularna w schemacie Clifforda, interesująca mnie w tym artykule, znalazłaby miejsce zapewne bądź w strefie drugiej - ,autentycznych artefaktów”, którą badacz łączy $\mathrm{z}$ historią i folklorem, muzeami etnograficznymi, kulturą materialną, rzemiosłem - bądź w strefie czwartej („niesztuka” odtwarzana, komercyjna), łączonej przez niego ze sztuką dla turystów, towarami, zbiorami osobliwości i przedmiotami codziennego użytku (Clifford 2000: 242). Mogłaby też znaleźć się na pograniczu obu tych stref (taką możliwość Clifford również zastrzega dla różnych obiektów). Jeśli jednak uznać ją za przykład zjawisk ze strefy czwartej, to można wówczas spojrzeć na relację między strefą ,autentycznych arcydzieł” i „nieautentycznych artefaktów” jako na relację budowaną na niebezpieczeństwie rozmycia kulturowej wartości ${ }^{4}$. Bowiem przedmioty „niesztuki” będą stanowiły dla przedmiotów „sztuki” nie tylko zagrożenie związane z możliwością pozbawienia ich Benjaminowskiej aury. Ich obecność będzie również skłaniać do ciągłej refleksji nad niepewnym, przygodnym i kruchym statusem dzieł jako dzieł, podając tym samym w wątpliwość ich wysoko cenioną, elitarną i prestiżową pozycję (nie tylko mogą one przecież utracić swój status, ale mogą również być oceniane w świetle świeżo przybyłych do tej strefy przedmiotów, na których historia odcisnęła piętno nieautentyczności). Prace, które staną się przedmiotem moich rozważań, mogą być zatem postrzegane jako demony nawiedzające purystyczny sen o niezmąconych przestrzeniach sztuki (,wysokiej”?), w których choć jest miejsce na coraz więcej tak niejednoznacznych, jak i banalnych, zwykłych przedmiotów czy praktyk, to jednak z przestrachem, niedowierzaniem, ale i przekąsem spogląda się na kandydatów, którzy w tym nowym kontekście (sztuki) nie noszą ani śladu wybitnego indywidualizmu, ani nie określa ich walka z tą konwencją (wybitnego indywidualizmu).

${ }^{3}$ I tym samym nie uczestniczy w grze o stawkę, jaka toczona jest w tym polu. (Chodzi o odniesienie do pola artystycznego, rozumianego za Pierrem Bourdieu, jako sieć, konfiguracja pewnych relacji przyjmowanych między różnymi osobami i instytucjami, w ramach której właśnie toczy się gra o określoną stawkę, a tą w przypadku współczesnego pola artystycznego może być widoczność artystów/artystek [ale innych podmiotów znajdujących się w polu] i dostęp do instytucji, za którym idzie tak kapitał społeczny, jak i ekonomiczny) (Bourdieu 2007; Bourdieu, Wacquant 2001).

${ }^{4}$ Mimo że jak powie badacz, nie ma możliwości bezpośredniego transferu między tymi strefami najpierw „towary” muszą zostać naznaczone właściwościami strefy drugiej - jej tradycyjnym, „autentycznym” charakterem (Clifford 2000: 243). 


\section{Kłopotliwe definicje}

Dawniej - osławione ,jelenie na rykowisku”, dziś czę́siej pewnie - widoki Paryża i Nowego Jorku, storczyki, plaże, tańczące pary, mgły unoszące się nad łąką jedne i drugie są świadectwami popularnego gustu. Nabywane na jarmarkach, turystycznych placach miejskich, ale i na portalach aukcyjnych różnią się od „sztuki z Ikei” (produkowanej masowo i sprzedawanej w sklepach wielkopowierzchniowych) tym, że choć tak samo jak ona popularne, to jednak wyposażone są w większy ładunek indywidualności, związanej $\mathrm{z}$ ich tworzeniem, a często także sposobem ekspozycji ${ }^{5}$. Mimo to - jedne i drugie - zaspokajają potrzeby związane $\mathrm{z}$ dekoracją przestrzeni mieszkalnych i usługowych, a bezpośrednio - z chęcią otaczania się tym, co uważane jest za piękne. I choć zdawałoby się, że ,jelenie na rykowisku” to fenomen czasów PRL-u, wiele $\mathrm{z}$ nich znajdziemy także w mieszkaniach współczesnych, czasem zakurzonych, zalegających na szafach, czasem dumnie eksponowanych w reprezentacyjnych przestrzeniach domów. Zanim jednak przyjrzę się tym obiektom, przede wszystkim jako zagrażającym/nawiedzającym „Sztukę” (i czy rzeczywiście mamy do czynienia $\mathrm{z}$ takim niebezpieczeństwem?), chciałabym zapytać o ich „popularny” status - dlaczego traktujemy je jako obiekty sztuki popularnej? Co właściwie przesądza o usytuowaniu ich $\mathrm{w}$ tej przestrzeni i jak można tę przestrzeń scharakteryzować?

Sztuka popularna bywa sytuowana blisko sztuki masowej: „(...) rozumiem przez nią [sztukę masową - KS] sztukę popularna wytwarzaną i rozpowszechnianą za pomoca masowej technologii" (Carroll 2011: 12). W ujęciu Noëla Carrolla jednak ważniejszy od tego, co w tej definicji odnosi się do „popularnego”, będzie namysł nad specyfiką sztuki masowej, którą postrzega on jako przystępną w masowym odbiorze (Carroll 2011: 197). Richard Shusterman $\mathrm{z}$ kolei zwróci uwagę na rolę doświadczenia estetycznego, podejmując się obrony sztuki popularnej przede wszystkim ze względu na to, „iż dostarcza nam ona (nawet intelektualistom) zbyt wiele estetycznej satysfakcji, abyśmy mogli przystać na jej całkowite potępienie, uznając ją za coś niskiego, odczłowieczającego i estetyczne nieprawomocnego" (Shusterman 1998: 214). W książce Zrozumieć kulturę popularna John Fiske będzie natomiast argumentować za postrzeganiem kultury popularnej jako

kultur[y] ludzi podporządkowanych i pozbawionych władzy, w związku z czym wpisane są w nią zawsze znaczenia odnoszące się do stosunków władzy, ślady sił dominacji i podporządkowania, które znajdują się w centrum naszego systemu społecznego, a zatem i naszego społecznego doświadczenia. Jednocześnie kultura popularna wykazuje oznaki uchylania się od owych sił lub oporu wobec nich, a więc zaprzecza samej sobie (Fiske 2010: 5).

Już te trzy propozycje rozumienia sztuki i kultury popularnej (a jest ich przecież dużo więcej; chociażby kategoryczne głosy zadeklarowanych przeciwników - krytyków kultury/sztuki popularnej, takich jak Dwight Macdonald czy Clement Greenberg) uwidaczniają różne możliwe ujęcia i perspektywy postrzegania tego kulturowego zestawu wartości, praktyk i wytworów. Czerpiąc $\mathrm{z}$ tradycji brytyjskich studiów kulturowych, rozpatrujących kulturę popularną jako ,(...) znaczenia i praktyki wytwarzane przez szeroką publiczność w momencie odbioru" (Barker 2005: 78), ale

5 Te pierwsze częściej prezentowane są w domach lub przestrzeniach chcących cechować się „domowością”, bliskością, te drugie - częściej spotkamy w przestrzeniach określonych przez Marca Auge jako nie- miejsca (np. hotele, lotniska, galerie handlowe). Zdaję sobie jednak sprawę, że nie jest to sztywny podział (rozdzielenie miejsc prezentacji poprzez ich funkcję), a rozróżnienie na sztukę popularną niemasową i sztukę popularną masową jest dużo bardziej wieloznaczne i kłopotliwe. 
i inspirując się ujęciem kultury wywodzącym się ze społeczno-regulacyjnej koncepcji kultury Jerzego Kmity (Kmita 2007), chciałabym zaproponować rozumienie sztuki popularnej z zachowaniem swoistego paradoksu, w moim przekonaniu warunkującego jej złożoną egzystencję.

Po pierwsze, będzie chodzić o sztukę, a więc o pewną szczególną dziedzinę kultury, która dzięki instytucjonalizacji zachowuje swoją autonomię (Dziamski 2001: 300). Instytucje sztuki i wspierające je dyskursy nie definiują sztuki, ale wskazują na nasze aktualne oczekiwania wobec sztuki oraz określają, jak sztuka może się do nich odnieść (Dziamski 2001: 300). Co więcej:

Kulturoznawczy punkt widzenia nie sprowadza się do analizy instytucji sztuki, nie jest bowiem socjologią sztuki. Zajmuje się raczej tym, jaki obraz sztuki buduje instytucja sztuki. Obraz ten jest tworzony przez dominujące w instytucji sztuki dyskursy, które nie tyle oddzielają, co wytwarzają praktykę artystyczną, często wbrew panującej kulturze artystycznej. Można zatem powiedzieć, że kulturoznawczy punkt widzenia zajmuje się procesem ramowania, czyli tym, jak świadomość artystyczna będąca częścią kultury, określa, czego w danym momencie oczekujemy od sztuki oraz co uważamy za ważne i wartościowe w działaniach aspirujących do miana sztuki, a więc w propozycjach wysuwanych jako kandydaci do bycia dziełem sztuki (Dziamski 2001: 301).

Przyjmując za Dziamskim (i pośrednio także za George'em Dickiem) szerokie rozumienie sztuki jako wytworów, pojęć i praktyk funkcjonujących w świecie sztuki (na który składają się tak jego instytucje, jak i rozmaite społeczne podmioty wytwarzające go i podważające), jednocześnie zakładam, że przestrzeń artystyczną ograniczają normy obowiązujące i dominujące w danym czasie oraz dyrektywy instruujące, jak te normy prawidłowo realizować. I mimo nasilających się od lat 60 . XX wieku tendencji do rozpatrywania sztuki jako dziedziny coraz bardziej egalitarnej, inkluzywnej i zwracającej się ku „zwykłemu”, nie zawsze przygotowanemu odbiorcy (Zob. np. Beuys 1987; Ostolski 2015 czy Bishop 2015) - jestem przekonana o funkcjonującym tak $\mathrm{w}$ społecznej percepcji, jak i w obiegu instytucjonalnym poglądzie o elitarnym i modernistycznym ${ }^{6}$ charakterze sztuki jako dominującym (co nie jest równoznaczne $\mathrm{z}$ takim postrzeganiem sztuki przeze mnie).

$\mathrm{Z}$ drugiej jednak strony chodziło będzie o praktyki, przedmioty i wartości „popularne”, czyli we współczesnych rozumieniach tego, co popularne - jako to, (1) co „powszechnie lubiane”, (2) związane z popularyzacją idei (w tym znaczeniu zachowany zostaje jeszcze dawniejszy komponent polityczny; przedstawianie wiedzy w sposób ogólnie przystępny), ale i jako to, (3) co związane z pewnymi uproszczeniami (Williams 1983: 111). Choć wskazuję na ten trzeci aspekt przypatrywania się temu, co popularne, to postaram się $\mathrm{w}$ swoich dalszych analizach nie kierować się tym rozpoznaniem, zawierającym w sobie element pejoratywnej oceny. Popularne będzie zatem przede wszystkim odnosić się do tego, co „powszechnie” rozpoznane i w jakiś sposób cieszące się uznaniem.

Chciałabym zatem zaproponować analizę osławionego ,jelenia na rykowisku" jako jednocześnie zjawiska artystycznego (rozpatrywanego w kategoriach wysokiego modernizmu i dyskursu instytucji sztuki) i popularnego; potraktować ten rodzaj przedstawień jako uwikłany $\mathrm{w}$ paradoks elitarności i powszechności, by następnie

\footnotetext{
${ }^{6}$ Chodziłoby o modernizm rozumiany w sztuce jako poszukiwanie czystego, autoreferencyjnego dzieła, modernizm, w którym ,produkcja i autorstwo sa wysuwane raczej na plan pierwszy niż ukrywane. Towarzyszy temu przeświadczenie uwidaczniające rolę artysty i formy; autorstwo nabiera samoistnej wartości artystycznej, przestaje być tylko środkiem reprezentowania »rzeczywistości«" (Abercrombie, Lash, Longhurst 2004: 393).
} 
rozważyć jego status jako kulturowego artefaktu podważającego granice między autonomiczna sferą sztuki a komercyjną, odtwarzana przestrzenią towarów (określenie Clifforda, Clifford 2000: 232). Przy czym rozpatruję to zjawisko przede wszystkim w jego wymiarze semantycznym, nie zaś formalnym.

W tym kontekście istotne jest także to, że nie będzie chodziło o sztukę wytwarzaną masowo (wiele egzemplarzy tej samej pracy tworzonych za pomoca maszyny), ani o sztukę postrzeganą jako ludowa, związana ze wsią (choć na trudności z jej współczesnym określeniem i niebezpieczeństwa czyhające na zbyt łatwe wpisanie jej we współczesną wieś zwracał uwagę Czesław Robotycki (Robotycki 2013: 1-13). Przedmiotem mojej analizy będą zatem prace tworzone ręcznie, a jeżeli nawet powielane technicznie - to w taki sposób, by tę techniczną reprodukcję zamarkować i zasugerować ,autorski sznyt” danego dzieła.

\section{„Jelenie na rykowisku” - motyw malarski}

Malowanie jeleni nie jest trudne - tak przynajmniej zakłada Aleksander Ledóchowski, który przedstawieniom tego zwierzęcia w malarstwie polskim poświęcił przenikliwy artykuł (Ledóchowski 1974). Autor zwraca uwagę na konwencjonalność ujęć jelenia, na schematy umieszczania go w określonym krajobrazie (las, jezioro, polana) o poranku, zmierzchu lub nocą (wówczas eksponowany jest księżyc), ale także na techniki malowania tych zwierząt:

Pierwszym $\mathrm{z}$ nich jest malowanie $\mathrm{z}$,pamięci”. Nie oznacza to jednak, że powstają one „Z wyobraźni”. Pamiętajmy, że jest to przede wszystkim towar na sprzedaż, podporządkowany bardzo ścisłej konwencji swego gatunku i wymaganiom nabywcy. Malowanie z pamięci oznacza w tym przypadku tyle samo, co przyswojenie sobie pewnego schematu i manualne kopiowanie bez konfrontacji z wzorem. Drugim wariantem tego sposobu jest malowanie scenerii z pamięci, natomiast motyw jelenia bywa przekopiowany $\mathrm{z}$,wzorowego" dzieła; w praktyce wiąże się to z techniczną trudnością oddania bardziej „naturalistycznie” figury zwierzęcia. Pozostałe sposoby wykazują już większy stopień organizacji pracy: albo wykonawca posługuje się gotowym szablonem, albo po prostu ręcznie wykańcza fotografię lub oleodruk (Ledóchowski 1974: 61).

Ledóchowski podkreśla aspekt techniczny wykonywania ,jeleni”, dostrzegając w opracowaniu motywu i jego realizacji szczególną wagę „malarskości” jako właściwości podnoszącej wartość tych przedstawień. I choć łączy nacisk na manualny charakter tych prac przede wszystkim z trudnościami związanymi z „posługiwanie[m] się urządzeniami do masowego powielania"7, to wskazuje w tym również na pewną rolę tradycji rzemiosła i warsztatu (Ledóchowski 1974: 61). Malarskość rozumiana jest tu jako wywoływanie poczucia głębi w obrazie, uwidocznienie na jego powierzchni śladów pędzla, nasycenie barwą, ale i tworzenie iluzji, bliskie realizmowi. Wywołaniu tych efektów ma służyć odręczna, przynajmniej w części, praca nad obrazem. To wykorzystanie realistycznej formy w służbie modernistycznemu „kultowi” autorstwa. Bo choć tego rodzaju przedstawienia czerpią przede wszystkim $\mathrm{z}$ konwencji realistycznych, to manualny tryb powstawania obrazów ma zaświadczać o ich jednostkowym, indywidualnym i autorskim właśnie charakterze, a tym samym kreować i podtrzymywać jego symboliczny prestiż. Z drugiej strony istotne okazuje się wskazanie na tradycję rzemiosła, która podtrzymuje przywiązanie do traktowania sztuki w kategoriach umiejętnej produkcji.

W charakterystyce ,jeleni na rykowisku" ważną rolę odgrywa także „plastyczność”, którą Ledóchowski tłumaczy: ,jest to tak, jak gdyby obraz powstawał

\footnotetext{
${ }^{7}$ Tak o charakterze technicznym, jak i prawnym czy finansowym, na co zwraca uwagę sam autor.
} 
z nalepiania poszczególnych motywów; ubocznym skutkiem tej konwencji jest subiektywne wrażenie zbliżone do tego, jakie występuje, gdy oglądamy dekoracje teatralne” (Ledóchowski 1974: 64). A z „plastycznością” łączy się „teatralność”:

O ile kompozycja obrazu i figuratywny sposób traktowania ujęcia są w bardzo szczególnym znaczeniu „realistyczne”, to kolorystyka malowidła odbiega całkowicie od tego kanonu. Twórca „jeleni” kieruje się z całą oczywistością względami swojej „estetyki”; i w tym przypadku efektem tego jest wrażenie pewnej teatralności - sceny w sztucznych światłach i irrealnych barwach, ale przy tym nastrojowej i sugestywnej (Ledóchowski 1974: 65).

Inną wyróżnioną przez autora właściwością jest podkreślenie dostojności jelenia, ukazanie go w pełnej krasie, a nawet jego mitologizacja i idealizacja. Jest to spójne z dążeniami do ,jasności i czytelności”, choć jak powie dalej Ledóchowski, wytwórcy zależy też na ,efektowności obrazu i jego atmosferze. Przesłanki estetyczne - choćby to była estetyka »barbarzyńska« - są wyraziście odczuwalne; obraz odwołuje się do tej sfery doznań, która nie wiąże się bezpośrednio z codziennym życiem" (Ledóchowski 1974: 65). Warto dlatego w ,jeleniu na rykowisku” dostrzec pewną paradność i jednocześnie emocjonalny oraz estetyczny nadmiar, dekoracyjność nastroju, efektowność, które mają urzekać i sprawiać przyjemność odbiorcom. Jak zauważy Anna Kunczyńska-Iracka, zamiłowanie do ,parady” jest zakorzenione w kulturze popularnej baroku i typowe jest dla polskich chłopów, dla których mogło być „synonimem piękna estetycznego”(Kunczyńska-Iracka 1988b: 233). Pociąg do wystawności i piękna (którego kryteria wyznaczały zmieniające się konwencje estetyczne) stanowił zresztą nieodłączną część kultury ludowej. Wydaje się jednak, że ta paradność nie będzie wyróżniać tylko kultury ludowej, odnajdziemy ją również na miejskich jarmarkach i bazarach w XIX i XX wieku, a na ulicach podczas festynów i na internetowych aukcjach - w wieku XXI.

Charakteryzując ,jelenia na rykowisku” jako motyw malarski, Ledóchowski ostatecznie postrzega go jako wizualną sublimację pożądania, seksualności, które nie były obecne w polskiej sztuce aż do wieku XX (z małymi wyjątkami):

Gdy w Italii i w innych krajach europejskich malarstwo kierowało myśli ku radościom tego świata, nasza rodzima twórczość specjalizowała się w nagrobkach, malarstwie trumiennym i ewentualnie portretowaniu antenatów. Gdy na całym świecie odsłaniano zasłonę buduaru, u nas odwalano grobowcową płytę. Jeśli w epokach późniejszych, w okresie rokoka, klasycyzmu i w XIX w., wyjątkowo pojawiały się obrazy o treści erotycznej, były dziełem malarzy obcych (...). Jeszcze i w XX wieku ci, którzy przeciwstawili się purytanizmowi, mieli u nas ciężki żywot (np. Boy-Żeleński). W rezultacie artystyczny problem kobiety i miłości u nas i gdzie indziej ma się z grubsza tak, jak Marysia Połaniecka do pani Bovary. W sztuce nastąpiło wielowiekowe zachwianie proporcji, które rzutowało na naszą mentalność. (...) Tak powstała pewna próżnia. Dużą rolę odegrała tu na pewno historia narodu, ale jeszcze większą purytanizm i tak typowa dla nas pruderia. Próżnię tę zajęły ,jelenie”. Pojawiły się w końcu XIX w., gdy w Warszawie około 60 procent ludności stanowili analfabeci, a w małych miasteczkach na wsi procent ten był znacznie wyższy. Dlatego jedyną formą dostępną powszechnie było malarstwo ${ }^{8}$ (Ledóchowski 1974: 71-72).

„Jelenie” miałyby więc zastępować przedstawienia o charakterze erotycznym, stanowić symboliczne wyobrażenie seksualnych doznań. Stanowią ,pewne misterium, którego się nie ogląda, tylko domyśla. W swoich intencjach obraz tworzy romantyczną

\footnotetext{
${ }^{8}$ Można mieć wątpliwości, czy to na pewno malarstwo pod koniec XIX wieku było jedyną powszechnie dostępną formą sztuki, bowiem ze względu na swoje ceny obrazy malarskie były mimo wszystko trudniej dostępne niż grafiki, ryciny czy rzeźby - zwłaszcza wśród ludności wiejskiej (Kunczyńska-Iracka 1988a).
} 
scenerię, atmosferę wzniosłości, która sprzyja podniesieniu biologicznego prainstynktu do rangi uroczystej celebracji. Nastrój powstaje jakby z dwóch elementów: miejsca (którym jest uroczysko) i jego przeznaczenia (biologicznego rytuału)" (Ledóchowski 1974: 68).

\section{Konwencjonalne, bliskie, codzienne...}

Z jednej strony ,jelenie” się podobają, podtrzymują wyobrażenia o przyrodzie jako „naturalnie pięknej”, a ich sposób ukazania (realistyczny lub silący się na realizm) zdaje się odnosić do trybów patrzenia na rzeczywistość zgodnych ze zdroworozsądkowymi rozpoznaniami i przyzwyczajeniami, co nie budzi większego zaskoczenia i funduje odbiorcy przyjemne ukojenie. $\mathrm{Z}$ drugiej jednak, ,jelenie" postrzegane właśnie jako niebudzące większych wątpliwości przedstawienia „natury”, odpowiadające popularnym wyobrażeniom, okazują się synonimem złego gustu, znakiem rozpoznawczym sztuki o „niskich” walorach artystycznych i estetycznych, przeciwko której występują ,elity”, które, jak powie Zygmunt Bauman, w „procesie cywilizacyjnym” dążą do oddzielenia się od „reszty”(Bauman 2012: 51):

$\mathrm{W}$ elitach proces ten [kulturowej desynchronizacji, określenie ZB - KS] rozbudził, z jednej strony, narastającą potrzebę samokształcenia, samodyscypliny i samodoskonalenia, z drugiej zaś coraz silniejszą skłonność do postrzegania „mas” - „uznawanych za brutalne, odrażające i całkowicie niezdolne do nabycia ogłady przez samodzielne zapanowanie nad namiętnościami” przez pryzmat biologii, medycyny, kryminalistyki oraz do ich coraz ściślejszego nadzorowania (Bauman 2012: 51-52)

Nie dziwi zatem, że przedstawienia ,jeleni na rykowisku” funkcjonują właśnie jako symbole ,złej sztuki” (określenie Marii Poprzęckiej) czy też kiczu, którego katalog właściwości proponuje Tomaš Kulka (Kulka 2013: 46-81). W tym miejscu trzeba jednak zaznaczyć, że zła sztuka i kicz nie muszą być tożsame, sztuka może być np. po prostu nieudana, epigońska, konwencjonalna, a kicz nie zawsze musi być zły (może być np. wykorzystywany strategicznie, jako narzędzie ironii). Poprzęcka zwraca uwagę, że złą sztuką mogą stać się prace uważane za arcydzieła na skutek ,popularności i popularyzacji, komercjalizacji i interpretacyjnych nadużyć" (Poprzęcka 1998: 121), a w tym wstępnym rozpoznaniu kryje się już wspominane wcześniej przeciwstawienie sztuki „wysokiej” (modernistycznej, trudnej, ale i funkcjonującej w swej niepowtarzalności) sztuce „popularnej” (rozumianej jako niska, ogólnodostępna, zwulgaryzowana). W tym kontekście badaczka mówi o banalizacji sztuki starożytnej (wszechobecne rzeźby klasyczne), ale i o wulgaryzacji takich dzieł jak Mona Lisa Leonarda da Vinci czy Dawid Michała Anioła. Za sprawą zwiększonej ogólnej dostępności do dzieł w instytucjach sztuki, ale przede wszystkim dzięki technicznej reprodukcji (Benjamin 1972), także w jej najnowszych XXI-wiecznych odsłonach, dotąd jedyne w swoim rodzaju, w pewien sposób unikatowe prace stają się nie tylko dość powszechnie znane (w granicach zachodniej kultury), ale i funkcjonują w swoich rozmaitej jakości, formy i kształtu - kopiach. Pozbawione zostają elitarności w dwójnasób: zaciera się granica między oryginałem a kopią, zanika aura niepowtarzalności, cechująca obiekty przypisane do określonego „tu i teraz” (Benjamin 1972: 154), tym samym przedmiot sztuki nie jest elitarny, bo nie jest jednostkowy, a dzięki wpisanej w niego wielości (funkcjonowanie w określonej/nieokreślonej liczbie egzemplarzy i wariacji) bądź kanałom komunikacji umożliwiającym zaprezentowanie go większej grupie ludzi - jego odbiorcą przestaje być jedynie elita, wąska, uprzywilejowana grupa ludzi. W tym kontekście szczególnie interesujące jest zwrócenie uwagi przez Poprzęcką na tylko pozorną otwartość definicji „sztuki” mimo 
zróżnicowanych wobec niej oczekiwań (powiązanych z wykształceniem, pochodzeniem, klasą itp. odbiorców, ale i twórców):

Nabywcy i amatorzy obrazów wystawianych na turystycznych szlakach, na paryskim Montmartrze, na Rynku Starego Miasta w Warszawie, na krakowskich starych murach, w różnego autoramentu galeriach - to nie „my”. Lecz jeśli - powtórzmy bez słowa „naszych” sztuką jest to, co daje się odnieść do zakresu oczekiwań wobec sztuki, to zaś, co artystyczne, jest rezultatem rodzaju postrzegania - jest to także sztuka, tylko że obliczona na zupełnie inny horyzont oczekiwań odbiorców. Nie „nas”. Wtedy istotnie zgodzić się można z definicją tegoż [Wernera - KS] Hofmanna: „Sztuka jest nie tylko tym, co spełnia określone oczekiwania przeżyć artystycznych ze strony wtajemniczonych lub tym, co pobudza ich nowe przeżycia, sztuka jest narzędziem do zaspokajania pozaartystycznych potrzeb”. Z jednej strony zatem „otwarte” na arbitralne decyzje artystów pojęcie sztuki stało się koniecznością wobec tendencji sztuki współczesnej, z drugiej jednak nie jest ono powszechnie akceptowane, nawet przez ludzi profesjonalnie ze sztuką związanych (Poprzęcka 1998: 154-155).

Mimo braku elitarności, ,jelenie na rykowisku” pozostają w obszarze sztuki: traktowane jako sztuka nieudana, kicz - ale i jako sztuka „blisko życia”, zakorzeniona w codziennych doświadczeniach, a dzięki temu bardziej zrozumiała, podobająca się, piękna. I także w jakiś sposób „prawdziwa”. Poprzęcka bowiem, pisząc o złej sztuce, wskazuje na „nierozdzielność kryteriów estetycznych, etycznych i poznawczych” (Poprzęcka 1998: 245). Złą sztuką będzie sztuka „nieprawdziwa, to znaczy udająca coś, czym $\mathrm{W}$ istocie nie jest. $\mathrm{W}$ »nieprawdziwości« zawierają się wszystkie takie cechy jak imitatorstwo, nieautentyczność, zwodniczość, wtórność, pretensjonalność, stwarzanie pozorów. Zło tkwiące $w$ tej sztuce jest więc przede wszystkim fałszem. Jest zaprzeczeniem nie sztuki, lecz prawdy" (Poprzęcka 1998: 244). Tym samym badaczka unika ostatecznie zrównania złej sztuki ze sztuką popularną. Jednocześnie wskazuje na trybsytuowania sztuki w świecie - na konieczność łączenia jej ze społecznością, wspólnotą, które to więzi uprawomocniają jej znaczenia, czynią ją sensowną. Podkreśla także, że ,zła sztuka to taka, która nie stawia żadnych wymagań, zwalnia z wszelkiego trudu, podsuwa łatwe poczucie samozadowolenia" (Poprzęcka 1998: 302) - niezależnie od tego, czy jest sztuką „wysoką” czy „niską”, dawną czy współczesną.

Konstatacje Marii Poprzęckiej pozwalają umieścić ,jelenie na rykowisku” i inne dystrybuowane według podobnych zasad przedstawienia (inne zwierzęta, ale i akty, obiekty, postaci religijne czy krajobrazy) w kontekście życia codziennego, które nie musi oglądać się na zinstytucjonalizowany świat sztuki. Niezależnie od tego, czy są to obiekty „prawdziwe” estetycznie, etycznie i poznawczo (by odnieść się do wcześniejszego rozpoznania warszawskiej badaczki), prezentowane na nich treści odnoszą się bądź do rzeczywistego, bądź do wyimaginowanego (marzonego czy też konstruowanego na bazie znanych obrazów z kultury popularnej), ale na pewno do w jakiś sposób bliskiego, „życiowego" repertuaru komunikatów wizualnych. Ta „bliskość” czyni je właśnie pracami popularnymi. I nawet gdy mamy do czynienia z twórczością abstrakcyjną, to jeśli zdążyła się zadomowić w społecznej wyobraźni, staje się ona twórczością popularną, bliską życiowemu doświadczeniu (to bowiem współtworzy $\left.{ }^{9}\right)$.

${ }^{9}$ Zob. projekt duetu artystycznego Vitaly’ego Komara i Alexandra Melamida, realizowany w latach 1994-97 zatytułowany People's Choice, polegający na sprawdzeniu, jakie obrazy są najmniej i najbardziej pożądane w różnych krajach świata. Jak przekonywali artyści, np. w Holandii najlepiej przyjmowana jest twórczość abstrakcyjna, nieprzedstawiająca w rozmiarze drukowanego magazynu, a np. w Turcji entuzjazm wzbudza widok bawiących się na skałach dzieci (obraz wielkości zmywarki do naczyń). Zob. więcej: http://www.komarandmelamid.org/chronology.html (dostęp: styczeń 2018), 
Do kwestii nieco inaczej rozpatrywanej „bliskości” odnosi się również Tomaš Kulka. Rozprawiając o kiczu (który nie jest w jego ujęciu po prostu złą sztuka), podnosi on problem odniesienia go do rzeczywistości, zdając sprawę z tego, że w przypadku kiczu na pierwszy plan wysuwa się przedstawiona na obrazie treść i jej funkcja referencyjna właśnie (aniżeli sposób wykonania, forma samej pracy). I choć czeski badacz skrupulatnie opisuje kolejne właściwości kiczu (tak estetyczne, jak i artystyczne), szczególnie istotne w rozważanym kontekście „bliskości” omawianych prac wobec życia jest zwrócenie przez niego uwagi na rozpoznawalność prezentowanych obiektów i tematów, a także na uznanie ich za piękne lub silnie nasycone emocjami (Kulka 2013: 43). Owa rozpoznawalność wiąże się z konwencjonalnym ujęciem problemu lub wyborem tematu - oznacza zwrócenie się ku dobrze znanym obrazom i wyobrażeniom, których znajomość zakotwiczona jest w życiu codziennym. Obcowanie za sprawą pracy artystycznej z tym, co znane, wytwarza poczucie intymności, komfortu i bezpieczeństwa, które nie narusza ani społecznego imaginarium, ani nie deformuje zastanych reguł obyczajowych, ani nie podważa obowiązujących praktyk kulturowych.

\section{Między zjawiskiem artystycznym a popularnym}

Przywołana wcześniej propozycja Aleksandra Ledóchowskiego odczytania ,jeleni na rykowisku” jako zamaskowanych przedstawień erotycznych, choć nie musi być przekonująca - kiedy odrzucimy perspektywę psychoanalityczną - zdaje sprawę $\mathrm{z}$ wywrotowego potencjału tych obrazów. W tym ujęciu naruszają bowiem one konwencjonalnie przyjętą narrację o wpisanym w nie pięknie, wskazują na tabuizowaną przestrzeń i rządzące nią demony. Co więcej, wydobywając z tych obrazów potencjał subwersywny, spostrzeżenia Ledóchowskiego prowadzą także do podkreślenia ukrytej w ,popularnych upodobaniach” wieloznaczności, która umożliwia rozmaite identyfikacje, ale i generuje sprzeczne, konfliktowe oceny tych prac.

Wydobycie $\mathrm{z}$,jeleni” potencjału wieloznaczności czyni je jeszcze bardziej popularnymi ${ }^{10}$, otwierając na szereg zróżnicowanych, sprzecznych albo ambiwalentnych interpretacji. Z drugiej strony krajobrazy z jeleniami przyjmowane są z całym zestawem rytuałów właściwych kulturze „wysokiej”, modernistycznej, traktowanej jako oddzielona od rzeczywistości potocznej uświęcona sfera sztuki ${ }^{11}$. Wynika to, po pierwsze, z założenia o ,autorskim”, indywidualistycznym charakterze tych obrazów. Bo choć zdarza się, że autor nabytego na miejskim rynku pejzażu nie jest nam znany (nie rozpoznajemy nazwiska, czy też trudno je odczytać, dotrzeć do tego, kto jest autorem), to widzimy ślady, jakie po sobie zostawił. I tym niewątpliwym śladem będzie dukt pędzla, znaki nakładanej w określony sposób farby. Tak rozumiana obecność autora jest z gruntu modernistyczna (w perspektywie anglo-amerykańskiej, która nie utożsamia Wielkiej Awangardy z modernizmem (Felski 1995: 23)). Autorstwo wiąże się także $\mathrm{z}$ Benjaminowską aurą, dzieło jako tworzone ręcznie, nawet jeśli w temacie czy formie zwyczajnie konwencjonalne - jest niepowtarzalne, jednostkowe. I w zgodzie z nowoczesnym przekonaniem, że to co oryginalne jest bardziej pożądane aniżeli to, co powtarzalne - paradoksalnie wykonywane ręcznie konwencjonalne przedstawienia jeleni na rykowisku mają większą wartość niż reprodukowane za

http://awp.diaart.org/km/painting.html (dostęp: styczeń 2018).

${ }^{10}$ Zob. uwagi J. Fiske, dotyczące polisemii (Fiske 2010: 5-6).

${ }^{11}$ Zob. interpretację modernizmu jako kultury wysokiej rozpatrywanej w opozycji do kultury masowej (Huyssen 1986: 44-62) 
pomocą maszyny nowatorskie $\mathrm{w}$ formie i treści dzieła sztuki konceptualnej czy postkonceptualnej $^{12}$.

Po drugie, ,jelenie” będą mieć znamiona kultury „wysokiej” (jeśli wyobrazimy ją sobie jako element osi wartościowania zjawisk kultury, gdzie po drugiej stronie znajdzie się kultura „niska”), kiedy weźmiemy pod uwagę sposoby ich ekspozycji, wskazujące na przypisywanie im dużej wartości symbolicznej. Często prezentowane są bowiem w ozdobnych ramach, które sugerują ich „dawne pochodzenie”, dostojność i powagę. Ramy stylizowane są na stare (odwołują się do barokowych, rokokowych czy klasycystycznych konwencji), bogato rzeźbione, imitują złoto, epatują przepychem, luksusem i szykiem, co może wskazywać na niedostępność, elitarność, niepospolity charakter umieszczonych w nich przedstawień, jak i samego obrazu jako obiektu. Tak prezentowane ,jelenie” umieszcza się często w przestrzeniach „reprezentacyjnych”, na ścianach w pokojach uważanych za najważniejsze w domu, ,pokojach telewizyjnych”, „gościnnych” i jadalniach, gdzie mogą być oglądane przez osoby przybywające z wizytą. Wskazują również na określony prestiż domostwa, nie tylko zdobią jego przestrzeń, ale i zaświadczają o materialnych i kulturowych zasobach ich posiadaczy, stając się atrybutami, ale i bezpośrednimi indeksami posiadanego dobra. W takiej perspektywie są one pełnoprawnymi „dziełami”, obiektami wyróżnionymi na tle przedmiotów użytkowych, które jak inne nowoczesne obiekty - choć pozbawione funkcji kultowej - zapraszają do kontemplacji, podziwiania i chcą być oceniane w kategoriach estetycznych.

Natomiast po stronie kultury „niskiej”, często potocznie utożsamianej z popularną, i przypisaniem do niej ,jeleni”, stoi w pierwszej kolejności ich powszechność, zainteresowanie nimi i obecność w wielu polskich domach. Ta egalitarność nasuwa zwątpienie w wyjątkowy charakter tych dzieł, każe zastanowić się nad oryginalnością wyborów ich właścicieli. Po drugie, ,jelenie” przedstawiają to, co przedstawiają, nawet jeśli kryją w sobie jakieś symboliczne odniesienia, są one w znacznym stopniu czytelne nawet dla niezbyt rzetelnie przygotowanego odbiorcy. Ta właściwość nasuwa wątpliwość - czy mamy do czynienia z „,dziełem sztuki”, skoro jest ono tak blisko życia, a jego treść (odniesienie) jest tak łatwo dostępne? ${ }^{13}$

\section{Między czy poza strefami?}

Obrazom przedstawiającym jelenie na rykowisku można przypisać cechy, które usytuują je w kontekście modernistycznie rozpatrywanej sztuki, ale i które zaświadczą o ich przynależności do obszaru sztuki popularnej. Ta wieloznaczność będzie podtrzymywana we wszelkich działaniach awangardowych (które nie respektują granic między sztuką a życiem, które zaburzają kategoryczne rozstrzygnięcia przyjęte w historii sztuki czy celowo, z rozmysłem mieszają elementy życia codziennego i sztuki), ale i w działaniach o charakterze komercyjnym, nastawionym na zysk, w których bliskość sztuki „wysokiej” (i związana z nią aura) ma legitymizować wytwory czy praktyki niekiedy niezbyt udane estetycznie czy artystycznie,

\footnotetext{
${ }^{12}$ Wskazuję tu na pewien paradoks, wynikający z możliwości co najmniej dwóch sposobów rozumienia oryginalności - jako niepowtarzalności i jako nowatorstwa.

13 W tym kontekście chciałabym zwrócić uwagę na jeszcze jedną sprawę: na ile wyjątkowość, oryginalność czy niepowtarzalność stanowią właściwości waloryzowane pozytywnie i dalej: kto odpowiada za te waloryzację i w jakim stopniu mają one charakter oddolny, a w jakim - produkują je np. dominujące dyskursy medialne?
} 
a pretendujące do Cliffordowskiej „strefy artystycznych arcydzieł”. Już pora zatem wrócić do rozważań amerykańskiego antropologa i zagadnienia autentyczności, na której opiera się zaproponowany przez niego podział kolekcjonowanych przedmiotów kulturowych. Clifford pisze, że przedmioty zgromadzone pod kategorią ,sztuka dla turystów, towary, zbiory osobliwości, przedmioty codziennego użytku" w rozważanym przez niego schemacie „sztuka - kultura” często zaczynają być wyposażane w ,aurę kulturowej twórczości", bez której nie mogłyby przemieścić się do strefy pierwszej („Bezpośredni ruch pomiędzy pierwszą i czwartą strefą jest niemożliwy”; Clifford 2000: 243). Owa aura jest warunkiem koniecznym, bez którego spełnienia przedmioty traktowane jako sztuka dla turystów nie miałyby szans zaistnieć w instytucjonalnym świecie sztuki. Co więcej, badacz zwraca uwagę, że autentyzm, który te podziały funduje (ale i którego płynność zaświadcza też o ich niestabilności), ,wytwarza się (...) w trakcie usuwania przedmiotów i zwyczajów z ich bieżącej sytuacji historycznej teraźniejszości-stającej się-przyszłością" (Clifford 2000: 246). Chodziłoby zatem o takie sytuacje, w których kolekcjoner, nabywca przedmiotów docieka ich „naturalnego”, oryginalnego, pierwotnego kontekstu kulturowego, kontekstu, w którym zaistniały publicznie, zrodziły się w rękach swojego twórcy, w jakiś sposób otrzymały widoczność. Przedmioty zyskują autentyczność, kiedy wydobyte $\mathrm{z}$ istotnego dla ich interpretacji kontekstu, zaczynają funkcjonować w świecie sobie obcym, a mimo to zachowującym pamięć o ich oryginalnym pochodzeniu.

Jeśli nie przypiszemy ,jeleniom na rykowisku” i innym wytwarzanym na podobnych zasadach obrazom autentyczności, kiedy oglądamy je na internetowych aukcjach czy na straganach na rynkach w polskich miastach i miasteczkach, zrobią to ich nabywcy. Im zakupione prace, umieszczone w przestrzeniach prywatnych, będą mówić jakąś „prawdę” o ich własnym doświadczeniu, przywołają pamięć związaną z sytuacją nabywczą - rozmowa ze sprzedawcą (czasem samym artystą) i wpisanie pracy w pejzaż „malowniczego ryneczku” czy „spektaklu żywych uliczek” (celowo przywołuję określenia z repertuaru artystyczno-teatralnego) nadadzą obrazowi atrybut „bliskości”, wskażą na emocje, które w danym momencie stały się impulsem do uruchomienia kolekcjonerskiej pasji. Innymi słowy, autentyzm, o którym pisze Clifford, czy prawdziwość, na którą wskazuje Poprzęcka, stanowią nie tyle część samego obrazu, co odsyłają do doświadczenia podzielanego przez nabywcę, widza, kiedy mowa o prywatnych kontekstach ekspozycji, i do doświadczenia twórcy i jego intencji, kiedy mowa o kontekście instytucjonalnym. Tu dobrym przykładem może być wystawa organizowana w 2012 roku w Muzeum Sztuki Nowoczesnej - Nowa sztuka narodowa ${ }^{14}$, prezentująca ,artefakty [które] powstały w większości poza oficjalnym obiegiem sztuki współczesnej - często w drodze działań grupowych, współpracy i w bezpośrednim zaangażowaniu w zmianę rzeczywistości" ${ }^{15}$. Owe artefakty to m.in. oprawa wizualna meczu piłkarskiego Legii Warszawa i ADO Den Haag z 2010 roku czy makiety, zgłoszone na konkurs na pomnik w Smoleńsku (mający upamiętniać katastrofę smoleńską z 2010 roku). Powstawaniu tych prac nie towarzyszyła jednak (przynajmniej nie jako dominująca) myśl o ich artystycznym charakterze; ważniejsze było przekonanie o narodowej dumie i narodowej, religijnej wspólnocie kibicowskiej („Boże, chroń fanatyków” - hasło eksponowane na wystawie) czy chęć upamiętnienia, podtrzymywania i kultywowania określonej wizji katastrofy smoleńskiej. Jednak kuratorzy wystawy umieścili te artefakty w przestrzeni instytucji sztuki. I nie zrobili

${ }^{14}$ Nowa sztuka narodowa. Realizm narodowo-patriotyczny w Polce XXI wieku, kuratorzy: Sebastian Cichocki, Łukasz Ronduda, Muzeum Sztuki Nowoczesnej, Warszawa 2.06 - 19.08.2012.

${ }^{15} \mathrm{https}: / /$ artmuseum.pl/pl/wystawy/nowa-sztuka-narodowa, dostęp: 15.01.2018. 
tego ze względu na ich wartość artystyczną (lub nie przede wszystkim - ze względu na nią), co raczej $\mathrm{z}$ powodu ich kulturowego rodowodu - zanurzenia w określonym doświadczeniu, uznanym za ,autentyczne”. Przedmioty te znalazły się w instytucji sztuki, a tym samym przynajmniej na jakiś czas został postawiony znak równości między nimi i innymi obecnymi tam obiektami, eksponowanymi w bardziej tradycyjnych kontekstach (co może brzmieć przewrotne, bo przecież współczesna sztuka często tradycję neguje lub próbuje o niej na różne sposoby zapominać). Oznacza to, że rozchwiana (choć tymczasowo) zostaje granica między autonomiczną sferą sztuki a zbudowaną często z towarów (choć te szybko zyskują indywidualne rysy) (Krajewski 2010) sferą życia codziennego. A działanie to zawdzięcza wiele afektywnemu wymiarowi praktyk nadawczych (producenckich) i odbiorczych, odwołującemu się chętnie do kontekstualizacji kulturowej, historycznej, religijnej, politycznej...

Być może rozpatrywane tu ,jelenie" nie tylko mają potencjał przemieszczania się między opisanymi przez Clifforda głównie w kontekście przedmiotów „egzotycznych” strefami systemu „,sztuka - kultura”, znajdując się raz w sferze autentycznych arcydzieł (zwłaszcza jeśli umieścimy je w przestrzeni instytucji sztuki, podkreślając ich walory estetyczne), raz w sferze autentycznych artefaktów (gdy położymy nacisk na ich rodowód), innym razem w obszarze nieautentycznych arcydzieł (kiedy istotny w ich interpretacji stanie się dla nas ich rys „,antyartystyczny”, negujący obowiązujące aktualne w sztuce kryteria i tendencje jak np. minimalizm) czy wreszcie w strefie nieautentycznych artefaktów (kiedy podkreślimy ich komercyjny wymiar, osiągany między innymi kosztem utrudniającej odbiór oryginalności czy nowatorskości rozwiązań formalnych). Być może - są one poza tymi strefami, jak obiekty religijne, o których Clifford powie, że „samodzielnie nie mają »mocy« czy tajemniczości, nie mają cech niegdyś charakterystycznych dla »fetyszy«, zanim jeszcze zostały przeklasyfikowane we współczesnym systemie jako sztuka prymitywna lub artefakty kulturowe” (Clifford 2000: 244). „Jelenie na rykowisku” oderwane od kontekstu PRLu, w którym zaświadczały o guście klas niższych, rzadko też dziś mających dostęp do wyspecjalizowanej, hermetycznej, sprofesjonalizowanej kultury artystycznej współcześnie znajdują się w przestrzeni gry i ciągłego konfrontowania ze sobą różnych postaw: ironicznego przechwytywania kultury popularnej przez elitarną, celowego zapożyczania atrybutów kultury modernistycznej przez popularną sztukę czy wreszcie dawania świadectwa alternatywnym wobec mainstreamu wartościom związanym z umiłowaniem przyrody czy erotyką (by przywołać rozpoznania Ledóchowskiego). Co więcej, ich „pierwotnymi” kontekstami, weryfikującymi ich „autentyczność” mogą być nie tyle warunki ich powstawania, co okoliczności ich nabycia czy oglądu. „Jelenie” są wieloznaczne, posiadają właściwości wskazujące zarówno na ich zagrażający wysublimowanym gustom potencjał estetyczny czy seksualny, jak i cechuje je możliwość wygaszania konfliktów, kojenia zakłopotania, odczytań prowizorycznych, łatwych i szybkich. Ta wieloznaczność może prowadzić też w stronę interpretacji ,jeleni” jako „osobistych fetyszy”, ale nie jako obiektów posiadających magiczną moc, $\mathrm{i}$ też nie jako ,przedmiotów dewiacyjnego czy egzotycznego »fetyszyzmu«, ale [właśnie jako - K.S.] naszych własnych fetyszy"(Clifford 2000: 248). I jak dalej powie Clifford:

Ta taktyka, z konieczności osobista, nadałaby kolekcjonowanym przedmiotom raczej siłe przykuwania uwagi niż samą tylko zdolność pouczania czy informowania. Jeszcze raz artefakty z Afryki czy Oceanii mogłyby stać się objets sauvages, źródłem fascynacji zdolnym wprawić w zakłopotanie. Widziane jako niepoddające się klasyfikacji, mogłyby nam przypominać 
o naszym braku zdolności posiadania siebie (...), o sztuczkach, do których się uciekamy, usiłując gromadzić świat wokół nas (Clifford 2000: 248).

„Jelenie” postrzegane jako osobiste fetysze mogą prowokować do zastanowienia się nad statusem współczesnych „dzieł sztuki” i ich miejscem w dzisiejszych tak prywatnych, jak i publicznych kolekcjach (osobnym tematem mogłoby być funkcjonowanie ,jeleni” w tradycji myśliwskiej). Wyposażone we właściwości pochodzące z odmiennych porządków kulturowych pokazują, jak kruche i tymczasowe mogą być ustanawiane w określonych środowiskach dystynkcje, jak łatwo może być obiektom przy sprzyjających okolicznościach przemieszczać się między Cliffordowskimi strefami. Same atrakcyjne przede wszystkim jako obiekty kulturowe swą obecnością w przestrzeni publicznej, ale i prywatnej, przypominają tak o zmieniających się „kryteriach awansu” do strefy autentycznych dzieł sztuki, jak i o wieloznaczności wpisanej w kulturę popularną. A ta ostatnia właściwość uczula na możliwość zróżnicowanych, ambiwalentnych czy nawet sprzecznych odczytań, które zabezpieczają przed kategorycznym deprecjonowaniem miłośników tych przedstawień.

\section{Bibliografia}

ABERCROMBIE, N., Lash, S., Longhurst B. (2004). Przedstawienia popularne: przerabianie realizmu (przeł. E. Mrowczyk-Hearfield). W: R. Nycz (red.), Odkrywanie modernizmu. Przekłady i komentarze (s. 381-416). Kraków: Universitas.

BARKER, Ch. (2005). Studia kulturowe. Teoria i praktyka (przeł. A. Sadza). Kraków: Wydawnictwo UJ.

BAUMAN, Z. (2012). Kultura jako praxis (przeł. J. Konieczny). Warszawa: PWN.

BENJAMIN, W. (1972). Dzieło sztuki w epoce możliwości jego technicznej reprodukcji (przeł. K. Krzemień). W: A. Helman (red.), Estetyka i film (s. 151-183). Warszawa: Wydawnictwa Artystyczne i Filmowe.

BEUYS, J. (1987). Każdy artysta (przeł. K. Krzemień). W: S. Morawski (red.), Zmierzch estetyki - rzekomy czy autentyczny? (s. 268-273). T.2. Warszawa: Czytelnik.

BISHOP, C. (2015). Sztuczne piekła. Sztuka partycypacyjna i polityka widowni (przeł. J. Staniszewski). Warszawa: Bęc Zmiana.

BOURDIEU, P. (2007). Dystynkcja. Społeczna krytyka wtadzy sądzenia (przeł. P. Biłos). Warszawa: Wydawnictwo Naukowe Scholar.

BourdiEU, P., Wacquant, L. (2001). Zaproszenie do socjologii refleksyjnej (tłum. A. Sawisz). Warszawa: Oficyna Naukowa

CARroll, N. (2011). Filozofia sztuki masowej (przeł. M. Przylipiak). Gdańsk: Słowo/obraz terytoria.

ClIFFORD, J. (2000). Kłopoty z kultura. Dwudziestowieczna etnografia, literatura i sztuka (przeł. J. Iracka $\mathrm{i}$ in.). Warszawa: Wydawnictwo KR.

Danto, A.C. (2013). Po końcu sztuki. Sztuka wspótczesna i zatarcie się granic tradycji (przeł. M. Salwa). Kraków: Universitas.

DZIAMSKI, G. (2001). Sztuka w perspektywie kulturoznawczej. W: B Kotowa, J. Sójka, K. Zamiara (red.), Kultura jako przedmiot badań. Studia filozoficzno-kulturoznawcze (s. 289-301). Poznań: Wydawnictwo Humaniora.

FELSKI, R. (1995). The Gender of Modernity. Cambridge, Massachusetts, London: Harvard University Press. 
FISKE, J. (2010). Zrozumieć kulturę popularna (przeł. K. Sawicka). Kraków: Wydawnictwo UJ.

HUYSSEN, A. (1986). After the Great Divide. Modernism, Mass Culture, Postmodernism, Bloomington, Indianapolis: Indiana University Press.

KMITA, J. (2007). Późny wnuk filozofii. Wprowadzenie do kulturoznawstwa. Poznań: Bogucki Wydawnictwo Naukowe.

KRAJEWSKI, M. (2010). Praca rąk we wspótczesnej sztuce. Manualność jako metafora. W: M. Krajewski (red.), Hand-made. Praca rak w postindustrialnej rzeczywistości (s. 57-67). Warszawa: Bęc Zmiana.

KulKA, T. (2013). Sztuka a kicz (przeł. K. Dudzic, A. Wanik). Wrocław: Galeria Miejska.

KUNCZYŃSKA-IRACKA, A. (1988a). Rzeźba, malarstwo, grafika - wprowadzenie. W: Fryś-Pietraszkowa, E., Kunczyńska-Iracka, A., Pokropek, M. (red). Sztuka ludowa w Polsce (s. 172-176). Warszawa: Arkady.

KUNCZYŃSKA-IRACKA, A. (1988b). Malarstwo. W: Fryś-Pietraszkowa, E., Kunczyńska-Iracka, A., Pokropek, M., Sztuka ludowa w Polsce (s. 209-237). Arkady, Warszawa.

LEDÓCHOWSKI, A. (1974). Jeleń na rykowisku. W: A. Helman, M. Hopfinger, M. Raczewa (red.), Szkice o sztukach masowych w Polsce (s. 57-74). Wrocław, Warszawa, Kraków, Gdańsk: Ossolineum, Wydawnictwo PAN, Instytut Sztuki.

OSTOLSKI, A. (2015). Wodiczko - Socjoestetyka. Warszawa: Wydawnictwo Krytyki Politycznej.

POPRZĘCKA, M. (1998). O złej sztuce. Warszawa: Wydawnictwa Artystyczne i Filmowe.

RовотYCKI, Cz.( 2013). Wspótczesna plastyka ludowa jako konwencja - uzupetnienia po latach. Prace Etnograficzne 41 (1), 1-13.

SHUSTERMAN, R. (1998). Estetyka pragmatyczna. Żywe piękno i refleksja nad sztuka (przeł. A. Chmielewski i in.). Wrocław: Wydawnictwo UWr.

TATARKIEWICZ, W. (2012). Dzieje sześciu pojęć. Warszawa: PWN.

Williams, R. (1983). Keywords. A vocabulary of culture and society. New York: Oxford University Press (revised edition). 
KAROLINA SIKORSKA

“DEER IN RUT": ON ART's DEMONS AND LIMITS OF POPUlAR ART

In this article I consider the role of popular artistic representations, first of all referring to perfectly known but ill-famed motive of "deer in rut". Starting with "art-culture", the scheme proposed by James Clifford, I try to argue for the fluidity and cultural contextualization of paintings which escape easy categorizations as bad art or kitsch. As a result, through the analysis of meanings of this kind of representations, I attempt to point out how these representations are situated both in the sphere of high (modern) art and in popular culture, still synonymous with low culture. I also show results of this polysemous entanglement. 